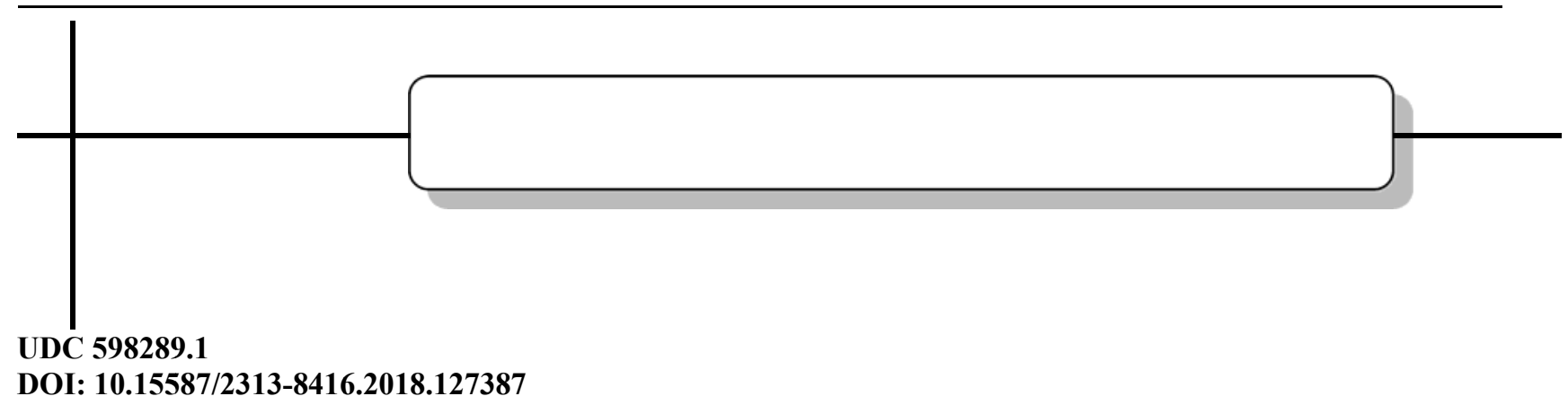

\title{
CLINICAL BLOOD ANALYSIS OF THE GREAT TIT PARUS MAJOR
}

\author{
(C) M. Drahulian, A. Chaplygina, N. Savynska, S. Kostenko, P. Buchek
}

Було проведено аналіз крові синиці великої на заповідній території Харкова «Гомільшанські ліси» у віковій динаміці постембріогенеза синиці великої. За допомогою власного розробленого методу взяття венозної крові з синуса ока встановлена ідентичність процентного показника лейкочитарної форми між літературними даними та нашими результатами, щу свідчть на користь застосування розробки. Дослідженні еритроцити, а саме, проведено мікроядерний тест, за результатами якого з упевненістю можна сказати, щзо вивчені особини не були схильні до ніякому хімічному або фізичному забруднення. Також в мазках крові не виявлено паразитарних інфекцій. У перспективі планується застосовувати метод взяття крові, з метою збору зразків для біохімічного і генетичного аналізів

Ключові слова: parus тајог, лейкочити, еритрочити, мікроядра, паразитарні інфекції, венозна кров

\section{Introduction}

Birds, being consumers of higher orders, are very sensitive to the impact of anthropogenic factors and often viewed as specific biological indicators of environmental quality [1]. The great tit is an optimal model species [2, 3], inhabiting both urban and forest areas. In literature we have found that Parus major can be a reservoir and carrier of many socially dangerous diseases, including ornithosis [4]. In this regard, the bird diseases, including those of the great tit, require timely and thorough diagnostics.

\section{Literature review}

The blood of all birds differs sharply from the blood of mammals, first of all, the presence of large elliptic nuclear red blood cells. The sizes of them are more often the sizes of leukocytes. The third group of formed blood elements of birds - platelets - also has a nucleus. This large number of nuclear cells makes it difficult to locate leukocytes in the blood of birds, while mammalian blood does not have such difficulties. The size of erythrocytes of birds $11-13 \times 7-8 \mu$; the size of the nuclei 5$6 \times 3-4 \mu$. Granulated erythrocytes are pretty much (2-3 $\%$, and sometimes much more).

Thrombocytes (spindle-like cells) are significantly less red blood cells $(8.5 \times 5,3 \mu)$. [5]. Leukocytes of birds, in general, are somewhat smaller than mammalian leukocytes.

Until now, the issue of whether the eosinophils from the special granulocytes (pseudo-inosinophils) should be distinguished in the blood of birds and differentiated eosinophils on round grains and palm grains [6].

Pseudo-eosinophils and eosinophils differ morphologically and functionally in the blood of birds. If, for example, pseudo-isinophils (especially young forms) have rounded grains similar to granules of eosinophils, then the edges of the granules of pseudo-ezinophils seem a bit "blurred", not sharp, compared to the granules of eosinophils. In the vast majority of pseudo-isinophils there is a rod-shaped grainy that often takes the form of the correct spindles. The kernels of mature pseudoezinophils, as well as granulocytes of birds in general, are more picnoty than the nuclei of mammalian granulocytes [7].

If the blood smear, pre-stained with 0.5 percent solution of eosin, is treated with a solution of acetic acid in alcohol, then the round grain of eosinophils persistently retains a red color, and the rod-shaped and round pellets of pseudo-ezinophils are discolored. The pellets of eosinophils are painted in Papaverilla in reddish-pink color, while the Brill-anticrisol blue is dyed in blue-pink.

When coloring a Gimza solution (even very good), pseudo-zinofil grain is very poorly painted, and therefore the color of the Romanovsky in the Pappenheim modification should be considered as the best color (and only fully suitable) for the blood of birds. Pseudoisinophils give a negative reaction. Grains are present only in eosinophils. The kernels in pseudo-ezinofilov are painted more lightly than eosinophils. Wirth believes that pseudo-ezinophil granules, even in the young stages of their development, are not round. They can be elongated, rod-shaped, spindle-shaped or rectangular. [8,9]

Pseudo-isinophils were pelletized during life-time rounds, and various modifications of their forms depended on fixation. Life-long round form of granules of pseudo-isinophils is still unlikely. But there is no doubt that the method of fixation may somewhat affect the shape of the pseudo-isinophilic grains. So, the author of this book, with some changes in the method of fixation received a special granulation of pseudo-isinophils, very similar to the mycelium of the fungus [10].

The atlas contains only those forms of cells that are definitely part of one of two groups of oxyphilic 
granulocytes of birds (and other farm birds) [9]. It is precisely in it that eosinophils are given, on the one hand, and the grains of pseudo-eosinophils, on the other. It is extremely difficult to distinguish between eosinophils and young (circular) forms of pseudoezinophils.

Lymphocytes of birds are usually small, often with characteristic protrusions (pseudopodias) formed by the cytoplasm. The latter in lymphocytes (even large ones) is poor.

Only the cytoplasm of monocytes is grayish-blue, close to the color of the cytoplasm of large lymphocytes. In the cytoplasm of monocytes of birds almost no azurophilic granularity was found [6].

Very characteristic of birds, the presence of strokes of peculiar decomposition of nuclei - the socalled "shadows" of the nuclei, indicating a very large lability, "fragility" of blood cells of birds. Particularly labile cells of very young animals. This complicates the counting of the leukocyte formula and may even distort the counting results $[6,11]$.

The blood of all species of birds is morphologically very close to the blood of chicken. Only pseudo eosinophils vary. In birds, their grainy does not have such clear spindle-like forms [10].

It is more likely to reminiscent of irregularly shaped short sticks, of uneven length. The eosinophils of turkeys are larger than pseudo-isinophils.

Thus, in the studied literature, we do not know the data on the leukocyte composition of birds in the nature reserve area, which led us to conducting research on the territory of National Nature Park "Homilshanski Forests" (Kharkiv Region, Ukraine).

\section{the study}

\section{The aim and objectives of}

The purpose of research was to study blood corpuscles and calculate the leukogram in great tits within the protected area.

To achieve this objective, the following tasks were set:

- to compare the leukogram in

different periods of postembryonic development of the great tit;

- to compare the number of micronuclei in erythrocytes of nestlings and adult birds; ied birds

- to identify the presence of parasites in the stud-

\section{Material and methods}

Our studies were carried out in Natural Nature Park "Homilshanski Forests" in the vicinity of Haidary Village (Zmiiv District, Kharkiv Region, Ukraine).

The leukogram was calculated according to the standard method in 21 birds, including 6 adults and 15 nestlings about 10-12 days old. The adult birds were captured with mist nets.
More often, an axillary vein is used for taking haematological material [10], but if the bird is small, let alone the nestling, the head decapitation is applied [12], or the blood is taken from the leg vein [13] or from the second finger of one of the legs after cutting off half or less of a claw phalanx [14].

We developed our own method of taking venous blood from birds. Thus, to take a blood sample, the venous sinus of the eye was punctured by a haematocrite capillary. Blood flowed into the capillary that for this purpose was selected ahead for each bird. With a light screw-like motion, we introduced a capillary under the eyeball, closer to the corner of the eye. The blood coming through the capillary was placed on a properly marked watchglass.

The blood was cleaned by a cotton swab and arrest of bleeding was controlled [10, 15]. After that, the smears were placed on slide plates with a help of a narrower bevelled-edge spreader slide. The blood smears were air-dried until a wet shine disappeared. After that they were fixed in Mai-Grunwald stain for 30 seconds, then rinsed with water and finally dyed in Romanowsky stain from 25 to 40 minutes. (Fig. 1) [7].

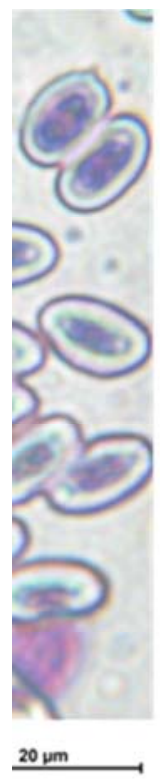

rus major)

The calculation of leukocytes for the identification of the leukogram pattern was carried out in the bird blood smears using a microscope with an immersion lens of 200 cells (50 in each corner) [16]. To calculate the leukogram a special keyboard calculator was used, each key marked with the initial letter of the leukocyte name [9]. The calculation of erythrocytes with micronuclei was performed for 1,000 cells [1].

\section{Results}

We studied 21 individuals of Parus major, including 3 females, 3 males and their posterity of 15 chicks, 10-12 days old. All results of the research are represented in Table 1. 
Table 1

Blood cell indices of great tits in different postembryonic periods

\begin{tabular}{|l|c|c|}
\hline \multicolumn{1}{|c|}{ Indices } & Nestlings $(\mathrm{n}=15)$ & Adults $(\mathrm{n}=6)$ \\
\hline \multicolumn{1}{|c|}{ Leukogram, \%: } & $3.4 \pm 0.45$ & $4.33 \pm 0.55$ \\
\hline humber of erythrocytes with micronucleus abnormalities & & \\
\hline heterophiles & $14.20 \pm 0.50^{*}$ & $16.66 \pm 1.33$ \\
\hline lymphocytes & $80.06 \pm 0.58^{* *}$ & $72.66 \pm 1.62$ \\
\hline moninophils & $3.73 \pm 0.30$ & $4.00 \pm 0.51$ \\
\hline basophils & $1.60 \pm 0.19^{* *}$ & $6.33 \pm 0.42$ \\
\hline
\end{tabular}

Note: $* p<0.05, * * p<0.001$ compared to adults

Table 1 shows that the average index of erythrocytes with micronuclei was equal to $3.4 \pm 0.45 \%$ in nestlings and $4.33 \pm 0.55 \%$ in adults, thus not differing significantly. However, the leukogram varied between representatives of different age groups: lymphocyte indices of nestlings were averagely higher by $7.4 \%$ (amounted to $80.06 \pm 0.58)(p<0.001)$, and the average monocyte indices were higher in adults by $4.73 \%$ (amounted to $6.33 \pm 0.42)(p<0.001)$. The percentage of heterophils in adults exceeded that of nestlings by $2.46 \%(\mathrm{p}<0.05)$. Such a difference between the percentages of the leukogram elements can be explained by physiological characteristics of different age groups.

Examination of the blood smears did not reveal any helminthic invasions.

\section{Discussion}

It is known that the haemogram of birds changes in the postembryonic period of their development. As the bird age increases, the number of leukocytes is almost doubled. This significant growth occurs at the expense of the increase of lymphocytes and decrease of eosinophils, thus forming the so-called system of physiological decussations at the moment of physiological maturity and at the beginning of egg-laying. This process has been observed by researchers on Haysex Brown chickens at the "Milana" poultry farm [17].

On the contrary, M.A. Derkho and M.A. Zubkova have established that the number of leukocytes decreases with age [22]. However, both authors come to the conclusion that during the period of physiological maturity the number of leukocytes is ranging within $28-30 \times 10^{9} / 1$. [11, 18].

Studies on the great tit, carried out by Priit Kilgas, have showed that the higher indices of lymphocytes were observed in mature age [19], compared to chicks [18]. The number of lymphocytes in adults ranged within $70 \%$ of the total number of leukocytes [20].

Studies of the haematological profile of great tits in the urbanized environment have revealed the following leukogram distribution in sexually mature individuals: the leukocyte profile was represented by lymphocytes $(67.2 \%)$, heterophils $(17.0 \%)$, monocytes $(8.3 \%)$, eosinophils $(7.2 \%)$, and basophils (0.3\%) [21]. Chicks in the urbanized conditions have showed the following distribution: lymphocytes (82.6\%), heterophiles (16.82\%), monocytes $(1.18 \%)$, eosinophils $(1.27 \%)$, and basophils $(0.2 \%)$ [18]. Lymphocyte indices of great tits, similar to domestic birds, decreases with age and the number of the monocytes (derivatives of the myeloid series) increases $[17,22]$.

Other indices do not change with age.

Our research found the same trend (Table 1) thereby providing evidence in favour of structural identity of the blood taken from the axillary vein and that taken by us from the eye sinus.

Examination of blood leukocytes are among commonly accepted techniques applying for the study of adaptive responses in animals and birds. The leukocyte dynamics reflects the degree of stress in each of the phases ("urgent adaptation", "long-term adaptation") [23]. However, erythrocytes are equally important in the examination of blood smears.

The calculation of micronucleus abnormalities (protrusions, constrictions and micronuclei themselves) allows the evaluation of ecological pressure affecting birds. For example, in case of excessive lead input, this parameter is almost doubled [8]. It is well known that excessive input of lead in the body inhibits heme synthesis, binds calcium ions, and damages the cordial muscle [24].

Our calculations of the micronuclei in nestlings and mature individuals of great tits showed that they did not exceed an admissible level of $5.6 \%$ [1], reflecting the favourable environmental situation of the studied region. The quantitative assessment of micronucleus abnormalities did not found any significant difference among the studied age groups.

\section{Conclusions}

The most important conclusion is that the blood taken from the eye sinus is venous and its structure does not differ from that taken from the axillary vein. This method can greatly facilitate for the researcher the task of taking haematological material from small birds. But in advance of this, we have received the following valuable results:

1. During the postembryonic development of great tits, their lymphocyte indices decrease and the number of heterophils and monocytes increases. Other leukogram elements do not change.

2. The index of the micronucleus test in nestlings and mature individuals of great tits was almost the same and did not exceed the admissible level.

3. No parasitic infections were detected in the blood smears.

\section{References}

1. Cea G. F. A., Etcheberry K. F. C., Dulout F. N. Induction of micronuclei in mouse bone-marrow cells by the flavonoid 5,3', 4'-trihydroxy-3,6,7,8-tetramethoxy-flavone (THTMF) // Mutation Research Letters. 1983. Vol. 119, Issue 3-4. P. 339-342. doi: $10.1016 / 0165-7992(83) 90182-3$ 
2. Gashkov S. I. Biologiya bol'shoy sinitsy (Parusmajor L.) yuzhnoy taygi Zapadnoy Sibiri: Abstract's PhD thesis. Tomsk, 2007. $24 \mathrm{p}$.

3. Grishchenko V. N. Sezonnaya dinamika polovozrastnoy struktury populyatsii bol'shoy sinitsy v Kanevskom zapovednike. Zapovidna sprava v Ukraini. 1995. Vol. 1. P. 48-51. URL: http://aetos.kiev.ua/selectrus/parus.htm (Last accessed: 12.01.2015)

4. Baryshnikov P. I., Bondarev A. Yu., Novikov N. A. Kharakteristika mikroorganizmov dikikh ptits lesostepnoy oblasti Altayskogo kraya // Vestnik Altayskogo gosudarstvennogo agrarnogo universiteta. 2010. No. 11 (73). P. 56-58.

5. Bityukov I. P. Izmeneniya kolichestva eritrotsitov i gemoglobina krovi v raznye periody vosproizvoditel'noy funktsii korov. Voronezh, 1979. No. 105. $162 \mathrm{p}$.

6. Irisova O. A., Irisov E Osobennosti gemotologicheskikh pokazateley u tipichno vysokogornykh ptits Azii: adaptatsiya na raznykh urovnyakh biologicheskoy integratsii. Tomsk, 1982. $197 \mathrm{p}$.

7. Almazov V. A., Ryabov S. I. Metody funktsional'nogo issledovaniya krovi. Leningrad, 1963. 132 p.

8. Kal-Kalif Ya. Ya. O leykotsitarnom indekse intoksikatsii i ego prakticheskom znachenii. Vrachebnoe delo. 1941. No. 1. P. 31-33.

9. Morfologicheskie i biokhimicheskie pokazateli krovi ptits plato Putorana / Irisov E. A. et. al. Tomsk, 1980. 143 p.

10. Metodika provedeniya nauchnykh i proizvodstvennykh issledovaniy po kormleniyu sel'skokhozyaystvennoy ptitsy: rekomendatsii / Imangulov Sh. A. et. al. Sergiev Posad: VNITIP, 2004. 43 p.

11. Green N., Stout U., Taylor D. Biologiya. Vol. 3. No. 2. Moscow: Mir, 1990. 193 p.

12. Donnik I., Derkho M., Kharlap S. Kletki krovi kak indikator aktivnosti stress-reaktsiy v organizme tsyplyat // Agrarnyy vestnik Urala. Ptitsevodstvo. 2015. No. 5 (135). P. 68-71.

13. Visser M. E., Lessells C. M. The costs of egg production and incubation in great tits (Parus major) // Proceedings of the Royal Society B: Biological Sciences. 2001. Vol. 268, Issue 1473. P. 1271-1277. doi: 10.1098/rspb.2001.1661

14. Valkyunas G., Yezhova T., Mironov S. Vysokie ekstensivnost' zarazheniya i raznoobrazie kroveparazitov u vorob'inykh ptits v Yuzhnom Turkmenestane // Parazitologiya. 2001. Vol. 35, No. 2. P. 135-142.

15. Paulke E., Haase E. A comparison of seasonal changes in the concentrations of androgens in the peripheral blood of wild and domestic ducks. General and Comparative Endocrinology. 1978. Vol. 34, Issue 4. P. 381-390. doi: 10.1016/00166480(78)90278-2

16. Vartanyan V. L., Karapetyan S. K. Metod ischisleniya formennykh elementov krovi ptits, amfibiy i reptiliy. DAN ArmSSR. 1959. Vol. 29, No. 2. P. 131-133.

17. Zashhitnye mekhanizmy ptitsy v postembrional'om razvitii / B. Bessarabov et. al. // Ptitsevodstvo. 2009. No. 10. P. $46-47$.

18. Izuchenie vliyaniya fosfoorganicheskikh pestitsidov na ptentsov bol'shoy sinitsy obitayushhikh v promyshlennykh sadakh: Proceedings / Miklyaeva M. et. al.; ed. by Vostretsov A. I. Neftekamsk, 2017. P. 34-39. URL: http://science-peace.ru/files/IPvSN_2017.pdf

19. Klinicheskie i biokhimicheskie pokazateli krovi ptits / Ponomarev V. A. et. al. Ivanovo: PresSto, 2014. $288 \bar{p}$.

20. Kilgas P. Blood parameters as indicators of physiological condition and skeletal development in great tits (parus major): natural variation and application in the reproductive ecology of birds. Tartu, 2007. 43 p. URL: http://dspace.ut.ee/bitstream/ handle/10062/4842/kilgas_priit.pdf

21. Gemato-biokhimicheskiy profil' model'nogo vida ptits na primere bol'shoy sinitsy (parus major 1.), obitayushhey v urbanizirovannoy srede / Khozina V. M. et. al. // Sovremennye problemy nauki i obrazovaniya. 2015. No. 3. URL: http://www.scienceeducation.ru/pdf/2015/3/104.pdf

22. Derkho M., Zubkova M. Znachenie gematomorfologicheskikh pokazateley v otsenke sokhrannosti ptits: Proceedings // Evolyutsiya sovremennoy nauki. Kirov, 2016. P. 40-42.

23. Buslovskaya L. K., Kovtunenko A. Yu. Kharakteristika adaptatsionnykh reaktsiy u kur pri vibratsionnom vozdeystvii raznoy chastoty i transportirovke // Sel'skokhozyaystvennaya biologiya. 2009. No. 6. S. 80-84.

24. Toksicheskoe vozdeystvie kadmiya i svintsa na serdtse: Proceedings / Stimmer K. et. al. // Gigiena okruzhayushhey sredy. Moscow, 1980. P. 28-32.

Дата надходження рукопису 02.02.2018

Maria Drahulian, PhD, Researcher, Department of Genetics, Breeding and Biotechnology of Animals, National University of Life and Environmental Sciences of Ukraine, Heroiv oborony str., 15, Kyiv, Ukraine, 03041

E-mail: parus_major@ukr.net

Angela Chaplygina, PhD, Professor, Department of Zoology, H. S. Skovoroda Kharkiv National Pedagogical University, Alchevskykh str., 29, Kharkiv, Ukraine, 61002

E-mail: iturdus@ukr.net

Nadiia Savynska, PhD, Assistant, Department of Zoology, H. S. Skovoroda Kharkiv National Pedagogical University, Alchevskykh str., 29, Kharkiv, Ukraine, 61002

Svitlana Kostenko, Doctor of Biological Sciences, Professor, Department of Genetics, Breeding and Biotechnology animals, National University of Life and Environmental Sciences of Ukraine, Heroiv oborony str., 15, Kyiv, Ukraine, 03041, E-mail: svitlanakostenko@i.ua

Polina Buchek, PhD, Junior Researcher, Department of Cell Regulatory Mechanisms, Institute of Molecular Biology and Genetics National Academy of Sciences of Ukraine, Akademika Zabolotnoho str., 150, Kyiv, Ukraine, 03143 